\title{
When knowledge management matters: interplay between green human resources and ecoefficiency in the financial service industry
}

\author{
Silvana S. Moraes, Charbel J. C. Jabbour Rosane A. G. Battistelle, Jonny M. Rodrigues, \\ Douglas W. S. Renwick, Cyril Foropon and David Roubaud
}

\begin{abstract}
The purpose of this work is to analyze the relationship between Green Human Resource Management (GHRM), especially environmental training, environmental empowerment and environmental teams, for the adoption of principles of eco-efficiency in the service industry sector. Therefore, we conducted a survey with more than 178 administrative employees of one of the largest financial banks in Brazil, which has been investing for more than 10 years in an eco-efficiency program. The survey results, based on Structural Equation Modelling, show that only environmental training positively influences the eco-efficiency in the studied company. The results indicate that training may be suffering with barriers to, in fact, support the empowerment and teamwork. In addition, the ecoefficiency program of the Bank would get benefits if provide more autonomy to employees and articulate environmental teams more intensely. To date, based on searchers performed on Scopus and ISI Web of Knowledge, this is the first work relating GRHM and eco-efficiency with a focus on service industry (Bank) with empirical evidence from Brazil.
\end{abstract}

Keywords: Eco-efficiency, Industry Sector, Banking, Green Human Resources, Sustainability, Training, Empowerment, Teamwork.

Of all the possible approaches to corporate environmental management, eco-efficiency has emerged as the one that can most immediately and consistently attract business people to the transition towards a more sustainable society. However, taking the AbilityMotivation-Opportunity (A-M-O) theory by Appelbaum, Bailey, Berg and Kalleberg (2000), as a context, it is clear that the practices of human resources are essential to increase the capacity, motivation and commitment of employees through training, performance management and reward, and the opportunity to share knowledge and involvement of workers in problem solving, as they assume greater responsibility for the tasks and decisions, However, environmental management literature has few studies on the importance of management processes that can facilitate and bring about improvements in environmental performance (Tung, Baird \& Schoch, 2014).

The integration of human resources and environmental management has led to an emerging area of knowledge, known as Green Human Resource Management (GHRM). Although the academic community has made progress in understanding how GHRM can contribute 
to the environmental performance of companies, the majority of works in the area are still conceptual, focusing only on manufacturing companies or are of a qualitative nature, based mainly on case studies. Furthermore, the relationship between eco-efficiency and GHRM has not been adequately explored. There is a significant gap on this relationship when considering the service industry sector. Finally there is also a significant gap of knowledge about the relationship of these issues in developing economies, especially in the BRIC (Brazil, Russia, India and China). Consequently, the objective of this study is to investigate the relationship among environmental

training, empowerment and

teamwork and eco-efficiency results in the context of a company's financial services sector in Brazil.

The relevance and originality of this study is justified because:

- Environmental training, empowerment and teamwork are key to a proactive environmental management but unfortunately they have not been connected to eco-efficiency;

- The majority of works in the field of GHRM or is conceptual, or is case study, requiring more quantitative studies, as developed here;

- The major focus of research in GHRM is on the manufacturing sector; the service sector has not been analyzed properly. In particular, the financial sector has been little studied;

There is also a gap related to the geographical area of this study. As suggested, more research on sustainability issues should be developed in developing countries, especially Latin America. Thus this research is an opportunity to know more about the relationship between GHRM and eco-efficiency in Brazil, which, according to PWC, will continue to maintain its position as one of the largest economies in the world for decades. The service sector in Brazil accounted for $69.4 \%$ of value added in GDP, as well as creates about 546,000 jobs.

\section{THEORETICAL BACKGROUND}

Several researches such as de Madsen and Hulhoi (2001), Unnikrishnan and Hegde (2007), Sammalisto and Brorson (2008), Prajolo, Tang and Lai (2014) have investigated how the environmental management system is implemented and diffused in companies. Other researches sought to understand and test empirically the factors that motivate and assist the implementation and maintenance of an environmental management system, such as Heras-Saizarbitoria, Arana1 and Boiral (2016). The critical points presented in the literature as barriers to their adoption are the qualification of employees and their willingness to make suggestions for improvement, and the management effort includes the participation of employees in decision making, including the essentiality of human factors in the search for (Kitazawa \& Sarkis, 2000), emphasizing empowerment, empowerment and shared management. Recent studies also show that employee training and training is directly linked to the maturity of environmental management in companies (Jabbour, 2015) and that training is the key to developing an 
environmental knowledge base, (Renwick, Redman \& Maguire, 2013). Joardar and Sarkis (2014), when analyzing the sustainability issue related to the institutionalization of companies that expand from developed countries to emerging countries, emphasize education as an essential factor for the success of the organization in the new territory. The studies emphasize the importance of human aspects in the achievement of organizational objectives related to sustainability and the importance of training people in the implementation, maintenance and improvement of organizational environmental performance.

Management systems have helped organizations in the implementation of environmental sustainability that by definition conservation and management of natural resources, as it goes beyond law enforcement or initiatives such as recycling and efficient use of energy resources, (Munck \& Borim de Souza, 2013), and the organization's need, from the perspective of the impacts of its operations and products on living and non-living natural systems, to minimize negative impacts and amplify positive ones, both in input and output processes , (Krajnc \& Glavic, 2005).

According to ISO 14001: 2004, an environmental management system is part of a management system to develop and implement environmental policy and manage its environmental aspects, a sustainable management approach that aims to engage in environmental processes and practices in order to To reduce the negative environmental impact generated by the company's activities (Gotschol, De Giovanni \& Vinzi, 2014).

The companies approach the protection of the natural environment in two ways: control and prevention (Del Brío, Junquera \& Ordiz, 2008) and develop in stages, which are reactive (penalties and sanctions), preventive (reduction of pollution) and proactive or strategic environmental management (environmental management as a pillar of competitive advantage), (JABBOUR et al., 2010).

There are economic advantages of adopting the principles of environmental management in organizations (Gotschol, De Giovanni \& Vinzi, 2014), reducing the use of resources, improving relations with public administration clients, improving image, market acceptance, Costs and adoption of environmental technology (Mártin-Peña, Diaz-Garrido \& SánchesLópes, 2014).

Tung, Baird and Schoch (2014) found a positive relationship between top management support, training and performance / rewards, and the effectiveness of the environmental management process. In the European context, Wagner (2015) found a positive relationship between EMS implantation and employee satisfaction and moderate relation with innovation.

\section{Ecoefficlency}

Ecoefficiency is defined as delivering goods and services that meet human needs and bring quality of life at 
competitive prices, progressively reducing the environmental impact and resource use throughout the product / service life cycle to a level of, At least estimated land capacity, it is about doing more by using less resources, stimulating creativity to develop new modes of producing goods and services (World Business Council for Sustainable Development - WBCSD) or how the interBetween the economic and environmental pillars. Eco-efficiency is the combination of the environmental and economic pillars, while reducing environmental impacts, promoting the rational use of natural resources (Savitz $\&$ Weber, 2007) or an instrument for the review of sustainability, as it indicates a relationship Empirical analysis of economic activities between environmental cost / value and ecological impact (Huppes \& Ishikawa, 2005).

Eco-efficiency is accompanied by advantages for companies, as it stimulates process optimization, transformation of waste into inputs for other activities, and boosts innovation and the creation of new products with new functions or with less negative impact on the environment (WBCSD) and directs the organization to a great competitive advantage in front of its competitors (Salgado, 2004), favor the minimization of environmental damages, the promotion of optimal conditions of occupational health and safety; Improving efficiency and competitiveness, which drive innovation; Improving reputation and relationships with environmental agencies and the community (Sisinno \& Moreira, 2005).

Human and organizational factors for ecoficlency

Human resource management practices can support the achievement of sustainability objectives and assist in the behavior of employees towards the environmental strategy and the objectives of the organization (Zibarras \& Coan, 2015)

The literature supports that employees should be encouraged and empowered to become aware of and take responsibility for managing environmental tasks (Tariq, Jan \& Ahmad, 2016). Zibarras and Coan (2015) argue that environmental training should be made available to all employees, Guercia and Carollo (2015), through case studies in six Italian companies, list eight existing paradoxes in GHRM practice that require managers to $B e$ worked in an aggregate and complementary way. Paille et al. (2014) states that there is a need to link environmental management and human resources in order to better understand how companies are able to achieve environmental performance.

A study conducted by Kaur (2011) among Malaysian company officials indicated that human resource factors (rewards, teamwork, training and empowerment) help organizations establish an effective environmental management system. In this way, special attention should be paid to the human and organizational aspects to successfully establish management systems that aim at environmental goals by the organization. In this article 
emphasis is given to three of these factors, environmental training, empowerment, and teamwork.

\section{Environmental training}

Vidal-Salazar, Cordón-Pozo and FerrónVilchez (2012), Ji et al. (2012) and Wagner (2013) suggest that it is important for members of the organization to understand the environmental impacts and policies of the organization through participation in environmental awareness training efforts that produce enduring knowledge and commitment.

Workforce education and training has been recognized as an essential ingredient in the promotion and implementation of environmental management practices in business organizations, (Madsen \& Ulhoi, 2011). A study by Daily and Huang (2001) identified human resource factors such as senior management support, environmental training, employee empowerment, teamwork, and reward systems as key elements of the implementation and maintenance process of a Environmental management system.

Training and training are relevant for managers as well as for other employees and employees demonstrate their training and qualification in the work teams, says Daily et al. (2012). Training / training is the most critical factor and without specific training, high levels of environmental development are not achieved and should be a priority for the company that wants to remain competitive and positively influence the development of pro-environmental strategies According to Vidal-Salazar, Cordon-Pozo and Ferron-Vilchez (2012). Ji et al. (2012) have shown that training employees according to demand has a direct and positive effect on the performance of companies in sustainable development and also moderates positively the relationship between the environmental attitude of a company and its performance in sustainable development.

A study by Tung, Baird and Schoch (2014), showed that organizations that provide more training are able to achieve better effectiveness in environmental management processes, recommending that all hierarchical levels should receive environmental training to raise awareness and knowledge. Dangélico (2014) states that companies should create a business environment characterized by high level of environmental awareness and guidance, providing adequate environmental training in order to increase their environmental competencies.

\section{Team work}

It is one that includes shared goals and objectives, mutual trust, decision making by consensus, cooperation, coordination and cohesion (Senior \& Swailes, 2007). In the context of environmental management in organizations comes the concept of 
green teams, or environmental teams, which Massoud, Daily and Bishop (2011) define as the one designed to solve environmental problems.

The use of green teams is an instrument for the greening of companies certified with ISO 14001 in Brazil, the company with more proactive and advanced environmental management uses green teams more intensively (Jabbour et al., 2013).

Green teams positively affect the organization's performance and environmental reputation (Dangélico, 2014), which contributes to the operational environmental performance (Tung, Baird \& Schoch, 2014), and the positive relationship between employee environmental Organizational performance is linked to teamwork (Tariq et al., 2016), and teamwork is a facilitator in the implementation and maintenance of environmental sustainability actions in organizations.

\section{Empowerment}

The term empowerment involves giving the worker power, responsibility, freedom and the ability to make decisions and act quickly without command when carrying out their daily activities, (Yavas et al., 2003), reflects the sharing of power with employees and the Autonomy for decision making in the workplace (Massoud, Daily \& Bishop, 2011), motivates the development of talents and experiences, giving the employee capacity and self-confidence to deal with gaps in customer service (Piaralal,
Mat, Piaralal, Bhatti, 2004) and influences the motivation to perform environmental tasks (Tariq et al., 2016). Supervisors must also be empowered, with the freedom and capacity to make decisions and make environmental commitments (Slatten, 2010).

Diduk (1999) argues that personal autonomy empowers individuals to become agents of change, contributing to the shift towards local environmental and cultural responsibility. A study by Massoud, Daily and Bishop (2011) also showed that empowering employees to make decisions regarding environmental issues is key to the success of EMS deployment in the enterprise.

Tariq et al. (2016) affirms that the environmental empowerment of employees must take place in a personal and individual way, incorporating in the literature the term emploee green empowerment.

In this way, empowerment is important for environmental actions to be carried out and for training and to act autonomously and decisively in environmental decision-making.

\section{CONCEPTUAL MODEL AND HYPOTHESES}

Eco-efficiency is an approach used for the analysis of environmental sustainability, indicating a relationship between economic activities and environmental cost or value of the environmental impact. It aims the delivery of goods and services that satisfy human needs and bring quality of life at competitive prices, progressively reducing the environmental impact and the 
use of resources throughout the product life-cycle management / service (WBCSD) or inter-relationship between economic and environmental pillars (Savitz \& Weber, 2007).

According to Salgado (2004), the inclusion of eco-efficient practices directs the organization to a greater competitive advantage over its competitors, and for this to occur there are three principles: reducing the consumption of natural resources, reduction the impact on the environment, which means the decrease in air and water pollution; and increased productivity or value of the product/service. The advantages are to minimize environmental damage, promoting optimal conditions of safety and occupational health improving the efficiency and competitiveness, improving the reputation and relationship with the organs environmental and community (Sisinno \& Moreira, 2005).

Green Human Resource Management aspects such as environmental training, teamwork and empowerment has been highlighted in the literature as collaborators in the implementation processes, improvement and communication of environmental practices in supporting organizations the organization towards environmental strategy

and environmental goals (Zibarras

\& Coan, 2015). Paille, Chen, Boiral and Jin (2014) states that there is a need to link environmental management and human resources in order to better understand how companies are able to achieve environmental performance.

Hale (1995) states that training and education are crucial to the success of the business and that the challenge to develop and use systems and techniques to manage environmental issues cannot be achieved without education and training of all employees.

Questions related to organizational culture and change management can inhibit the transformation of an organization in environmentally conscious (Perron, Côté \& Duffy, 2006). To overcome these limitations and succeed in implementing an green initiative or environmental policies require training (Vidal-Salazar, CordonPozo \& Ferronvilchez, 2012)

Capacity building and training are relevant for managers as well as for other employees, putting astraining the most critical factor to go achieve high levels of environmental development (Daily, Bishop \& Massoud, 2012; Ji et. al, 2012; Vidal-Salazar et al., 2012). Thus

$\mathrm{H}_{1}$ : Environmental training relates positively to the adoption of ecoefficiency in the business services sector.

Teamworking includes shared goals and objectives, mutual trust, making decisions by consensus, cooperation, coordination and cohesion and meets the growing expectations and capabilities of a workforce increasingly educated (Hodson, 2010). In the context of environmental management in organizations the concept of green teams is defined as a tool projected for solve the environmental $\mathrm{p}$ roblems (Daily et al., 2012). To be characterized as an environmental team the goal should be to reduce environmental impacts of the company, improve the natural environment and have voluntary participation by employees (Strachan, 1996), and green teams are ideal for environmental 
proactivity (Jabbour, Santos, Fonseca \& Nagano, 2013) and positively affect performance and environmental reputation the organization (Dangélico, 2015).

Teamwork contributes to the operational environmental performance, (Tung, Baird \& Schoch, 2014) and tends to mediate the relationship between environmental training of employees and organizational performance (Tariq, Jan \& Ahmad, 2016). Thus,

$\mathrm{H}_{2}$ : And teamwork relates positively relates to eco-efficiency in the business services sector.

The term empowerment involves to give to workers power, responsibility, freedom and ability to make decisions and to act quickly without commands to perform daily activities, (Yavas, Karatepe, Avci \& Tekinkus, 2003). Sharing power with the employees and giving them autonomy for decisionmaking (Massoud, Daily \& Bishop, 2011), add motivation to perform environmental tasks (Tariq et al., 2016). For this to occur, environmental training is necessary (Slatten, 2010).

Diduk (1999) states that personal autonomy allows the individuals to become gents of change, contributing to the shift towards environmental and cultural responsibility. Massoud, Daily and Bishop (2011) also showed that empowerment is fundamental to the successful implementation of Enviromental Management Systems in companies.

As a consequence,

$\mathrm{H}_{3}$ : Empowerment positively relates to eco-efficiency in the business services sector.

\section{RESEARCH METHODOLOGY}

A survey with self-administered questionnaire was used (Annex I), through SurveyMonkey tool. The data were collected through a questionnaire with closed questions sent to the employees who participated in classroom environmental training offered by the company between July / 2013 to June / 2014 in different regions of the country.

The research was done during 07/2013 to 06/2014, a total of 1104 participants, of which 178 responded to the survey sent. This sample is appropriate in view of the studies Vachon and Klassen (2008) (84 valid questionnaires), Hridlicka (2009) (59 respondents) and Marshall et al. (2015) (156 valid questionnaires).

The questionnaire was based on Dailly et al (2012) with 18 questions evaluated by the Likert scale of five points. The questionnaire was composed of the following questions: (1) Environmental Training (TA), with 6 issues (TA1TA6);. (2) Empowerment (Emp), with 3 questions (EMP1-EMP3); Environmental teams, with 2 issues (EQU1-EQU2); and Eco-efficiency (ECO1-ECO7).

Data were analyzed using the statistical tool of structural equation modelling (SEM). This choice is due to the fact that SEM presents the advantage of allowing analysis, simultaneously, the relationship between a large number of variables (Hair, Ringle \& Sarstedt, 2011). Ismail, Hamid and Idris (2012) also states that the SEM allows researchers to test more complex contextual frameworks ensuring a robust and holistic analysis. 
Table 1 - Descriptive analysis of items of concepts

\begin{tabular}{|c|c|c|c|}
\hline & Dimensions and questionnaire items & Average & Deviation \\
\hline OK & Environmental training for employees & & \\
\hline TA1 & $\begin{array}{l}\text { An adequate amount of training on environmental management is provided in } \\
\text { my work environment }\end{array}$ & 3.23 & 1.28 \\
\hline TA2 & $\begin{array}{l}\text { All co-workers that received environmental training can adopt appropriate } \\
\text { environmental practices }\end{array}$ & 3.74 & 1.27 \\
\hline TA3 & $\begin{array}{l}\text { I am satisfied with the offered environmental training and ease in performing } \\
\text { it }\end{array}$ & 3.65 & 1.21 \\
\hline TA4 & Employees receive regular environmental training & 2.44 & 1.27 \\
\hline TA5 & Employees use their environmental knowledge effectively & 2.94 & 1.18 \\
\hline TA6 & Employees have opportunities to apply their environmental training. & 3.48 & 1.25 \\
\hline EMP & Environmental empowerment of employees & & \\
\hline EMP1 & $\begin{array}{l}\text { Employees are free to make decisions about environmental management } \\
\text { aspects according to their job function }\end{array}$ & 3.31 & 1.27 \\
\hline EMP2 & $\begin{array}{l}\text { Employees have significant autonomy to address / resolve environmental } \\
\text { issues / problems }\end{array}$ & 2.97 & 1.29 \\
\hline EMP3 & $\begin{array}{l}\text { Employees are free to choose their own way of addressing environmental } \\
\text { issues. }\end{array}$ & 3.06 & 1.31 \\
\hline EQU & Team work for environmental purposes & & \\
\hline EQU1 & Employees often use teamwork to solve environmental issues. & 2.65 & 1.34 \\
\hline EQU2 & Employees often meet in teams to discuss environmental issues & 1.99 & 1.19 \\
\hline ECO & Eco-efficiency performance & & \\
\hline ECO1 & $\begin{array}{l}\text { Our environmental efforts have resulted in significant waste reduction in } \\
\text { agencies }\end{array}$ & 3.29 & 1.18 \\
\hline $\mathrm{ECO} 2$ & Our environmental efforts have resulted in improved quality of services & 3.26 & 1.22 \\
\hline ECO3 & We focus our environmental management to improve the company's reputation & 3.63 & 1.13 \\
\hline $\mathrm{ECO} 4$ & $\begin{array}{l}\text { Our environmental efforts have generated improvements in our working } \\
\text { environment }\end{array}$ & 3.52 & 1.14 \\
\hline ECO5 & $\begin{array}{l}\text { The benefit of environmental efforts have reduced the costs related to } \\
\text { processes, products and services }\end{array}$ & 3.58 & 1.10 \\
\hline ECO6 & $\begin{array}{l}\text { Our environmental efforts have contributed to the adoption of alternative } \\
\text { technologies and processes }\end{array}$ & 3.42 & 1.18 \\
\hline ECO7 & $\begin{array}{l}\text { Our environmental efforts has helped our company to develop new products, } \\
\text { services and processes }\end{array}$ & 3.27 & 1.20 \\
\hline
\end{tabular}

Source: Prepared by the author (2016).

All data were analyzed using the software STATA®12, maximum likelihood method for the model settings. The analysis was carried out in stages. It was necessary to check the reliability, convergent and discriminant validity of each construct using confirmatory factor analysis (Costa, 2011). It was later verified the nomological validity of the model. The indices considered were the CMIN / DF, p-value, TLI, CFI; RMSEA; SRMR 
and CD. The SRMR is the root mean squared residue were considered good adjustments that have a small amount, usually less than 0.08 . (Hancock \& Mueller, 2006). The CD is the coefficient of determination $\mathrm{R}$ as is a square for the entire model. A perfect fit corresponds to a CD 1 . Considering the collection of primary data, we adopted the test of single factor Harman (Podsakoff \& Organ, 1986) to measure the common variance to the method and to check that the respondents tended to answer it in a corresponding manner.

The environmental training construct showed a very close fit acceptable (CMIN / $\mathrm{DF}=5.10 ; \quad$ p-value $=0.002 ;$ TLI $=0.918$, CFI $\quad=0.958$, RMSEA $=0.102 ; \mathrm{SRMR}=0.044 ; \mathrm{CD}=0.833$ ) only the value of RMSEA $(<0.10)$ higher than recommended in the literature (Maroco, 2010). It was then found that the item "TA1 - An adequate amount of training on environmental management is provided in my work environment" presented a very low factor loadings (0.633) opted for the withdrawal of the item as it did not affect the settings the construct $(\mathrm{CMIN} / \mathrm{DF}=$ 3.038; $\mathrm{p}=0,010$; $\mathrm{TLI}=0,922$; CFI $=0,961 ;$ RMSEA $\quad=0,107 ;$ SRMR $=0,039 ; \mathrm{CD}=0,812)$. Even with high values for RSMEA. Another analyzed load low load was the item "TA6. - Employees have opportunities to apply their environmental training" with low explanation by the construct (0.663). It conducted the analysis of the construct with the item deletion producing acceptable adjustments (CMIN / DF $=2.269 ; \mathrm{p}$ $=0.103$; TLI $\quad=0.958$, CFI $=0.986$, RMSEA $\quad=0.084 ;$ SRMR $=0.028 ; \mathrm{CD}=0.794)$. It remained then the decision to withdraw the item construct. Reliability presented by Cronbach's alpha is high (0.773), up 0.70 what is considered acceptable for the proposed study (Hair, Black, Babin \& Anderson, 2005). Convergent validity was however lower than the amount considered appropriate by the literature $(>0.50)$ was chosen to keep the four items.

The empowerment construct features a super adjustment $(\mathrm{CMIN} / \mathrm{DF}=0.000$; TLI $=1.000, \mathrm{CFI}=1.000, \mathrm{RMSEA}=0.000$; SRMR $=0.000 ; C D=0.861)$. Thus, any preset in the construct was not necessary. Below the final values of the construct. It is still necessary to analyze the reliability and construct validity. The values for Cronbach's alpha (0.837) and for the calculation of internal validity (0.639)are acceptable. Something satisfactory since the withdrawal of items impairs the construct. Table 3 presents these results.

To validate the eco-efficiency of background, the model showed evidence of super adjustment due to the value 0.000 for RMSEA and 1,002 for TLI (CMIN / DF $=0.959 ;$ p-value: $0.518 ; \mathrm{TLI}=1.002, \mathrm{CFI}=$ 1.000, RMSEA $=0.000 ;$ SRMR $=0.034$; $\mathrm{CD}=0.990)$. In this way, not to have high values in the modification indices was decided to exclude the question "TA3 - I am satisfied with the offered environmental training and ease in performing it" due to low factor load the item in the model (0.600).

The withdrawal of the item did not bring significant changes to the adjustment values (CMIN / DF $=0.907$; $p$-value: 0.566; TLI $=1.004, \mathrm{CFI}=1.000$, RMSEA $=0.000$; SRMR $=0.029 ; C D=0.989)$, so we chose that for deleting the item. Still keeping the same initially observed problems, it was found that the factor loadings of the item 
"TA2 - All co-workers received value: $0.582 ;$ TLI $=1.006, \mathrm{CFI}=1.000$, environmental training can adopt appropriate environmental practices" was low (0.606) in this way was made of the model analysis without item.

The adjustment values without TA2 item no RMSEA $=0.000 ;$ SRMR $=0.026 ; \mathrm{CD}$ $=0.985)$, so we chose to keep the only model with TA4 and TA5 items composing the model of eco-efficiency record. Figure 1 shows the final model.

significant changes $(\mathrm{CMIN} / \mathrm{DF}=0.857$; $\mathrm{p}$ -

Figure 1- Model of Eco-efficiency background

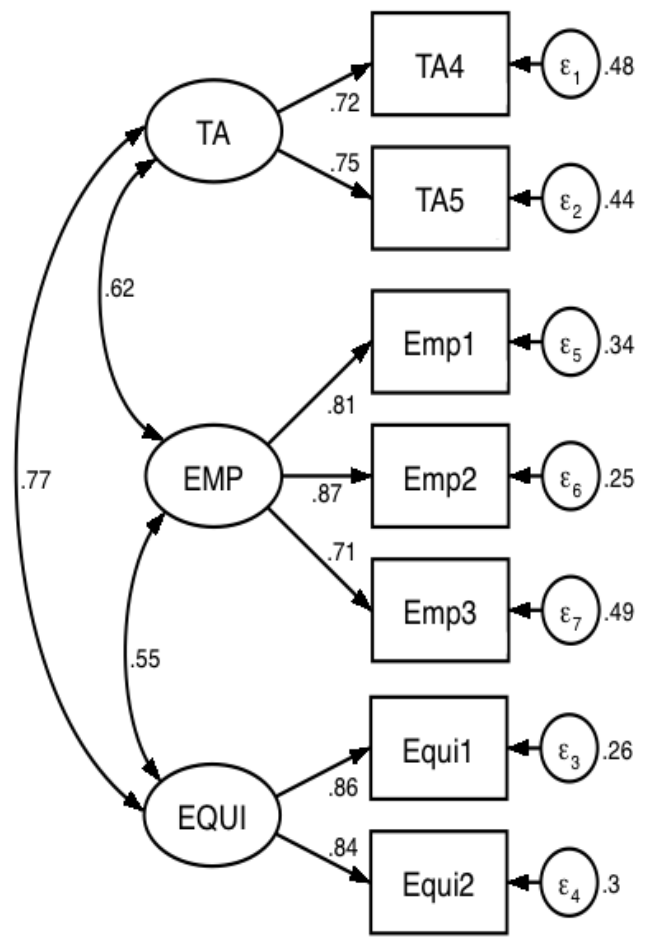

Source: Prepared by the author (2016).

Table 2 below shows the values of reliability and validity for converging each of the final constructs.

Table 2 - Reliability and convergent validity for the background of eco-efficiency

construct

Training teams

environmental empowerment

Teams of environmental work
Cronbach's alpha

0.703

0.837

0.836
Convergent validity

0.543

0.640

0.723

Source: Prepared by the author (2016).

It is still necessary to check the size of the discriminant validity (Costa, 2011) to see if the scales are distinct to the point of actually differ. 
Table 3 - Comparison of results obtained

\begin{tabular}{llll}
\hline & TA and EQUI & TA \& EMP & EMP and EQUI \\
Chi-square difference & 16.68 & 33.15 & 90.26 \\
Difference of degrees of freedom & 1 & 1 & 1 \\
P-value & $0.000 * * *$ & $0.000 * * *$ & $0.000 * * *$ \\
\hline
\end{tabular}

Source: Prepared by the author (2016).

* Significant at the level of $\mathrm{P}<0.10$. ** Significant at $\mathrm{P}<0.05$. *** Significant at $\mathrm{P}$ $<0.01$.

According to the results we can say that the constructs that precede the eco-efficiency are different. So we can say that the constructs have evidence to corroborate the hypothesis that are reliable, convergent and discriminant.

The eco-efficiency construct did not show an appropriate initial setting (CMIN / DF $=7.17 ; \mathrm{p}$-value $=0.000 ; \mathrm{TLI}=0.829, \mathrm{CFI}$ $=0.886$, RMSEA $\quad=0.186 ;$ SRMR $=0.061 ; \mathrm{CD}=0.914)$. Featuring a high value for the RMSEA and low values of TLI and CFI.

It was observed by modification indices that the error item "ECO1 - Our environmental efforts have resulted in significant waste reduction in agencies' showed values higher than expected (47.611) correlating with the other items.

The withdrawal of item improved construct settings (CMIN / DF $=3.895 ; \quad \mathrm{p}$ $=0.000 ;$ TLI $=0.929, \mathrm{CFI}$ $=0.957$, RMSEA $\quad=0.128 ;$ SRMR $=0.035 ; \mathrm{CD}=0.910)$. The RMSEA values were still higher than indicated as acceptable by the literature, but it was decided to keep the remaining items to the structural model. Figure 2 shows the final construct used. 
Figure 2 - Construct eco-efficiency

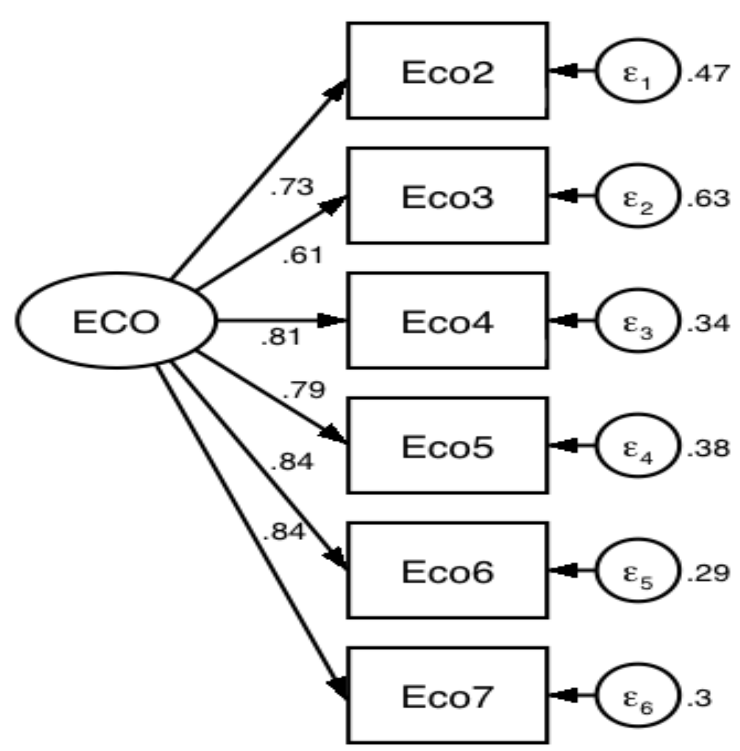

Source: Prepared by the author (2016).

Thus, we conducted the tests of reliability 4 shows the results obtained for the and internal validity to the construct. Table construct.

Table 4 - Reliability and convergent validity to construct eco-efficiency

\begin{tabular}{lll}
\hline construct & Cronbach's alpha & Convergent validity \\
ecoefficiency & 0.897 & 0.599 \\
\hline
\end{tabular}

Source: Prepared by the author (2016).

After analyzing each construct individually analyze the model. Figure 3 shows the final nomological validity was performed to model search. 
Figure 3 - Structural Research Model

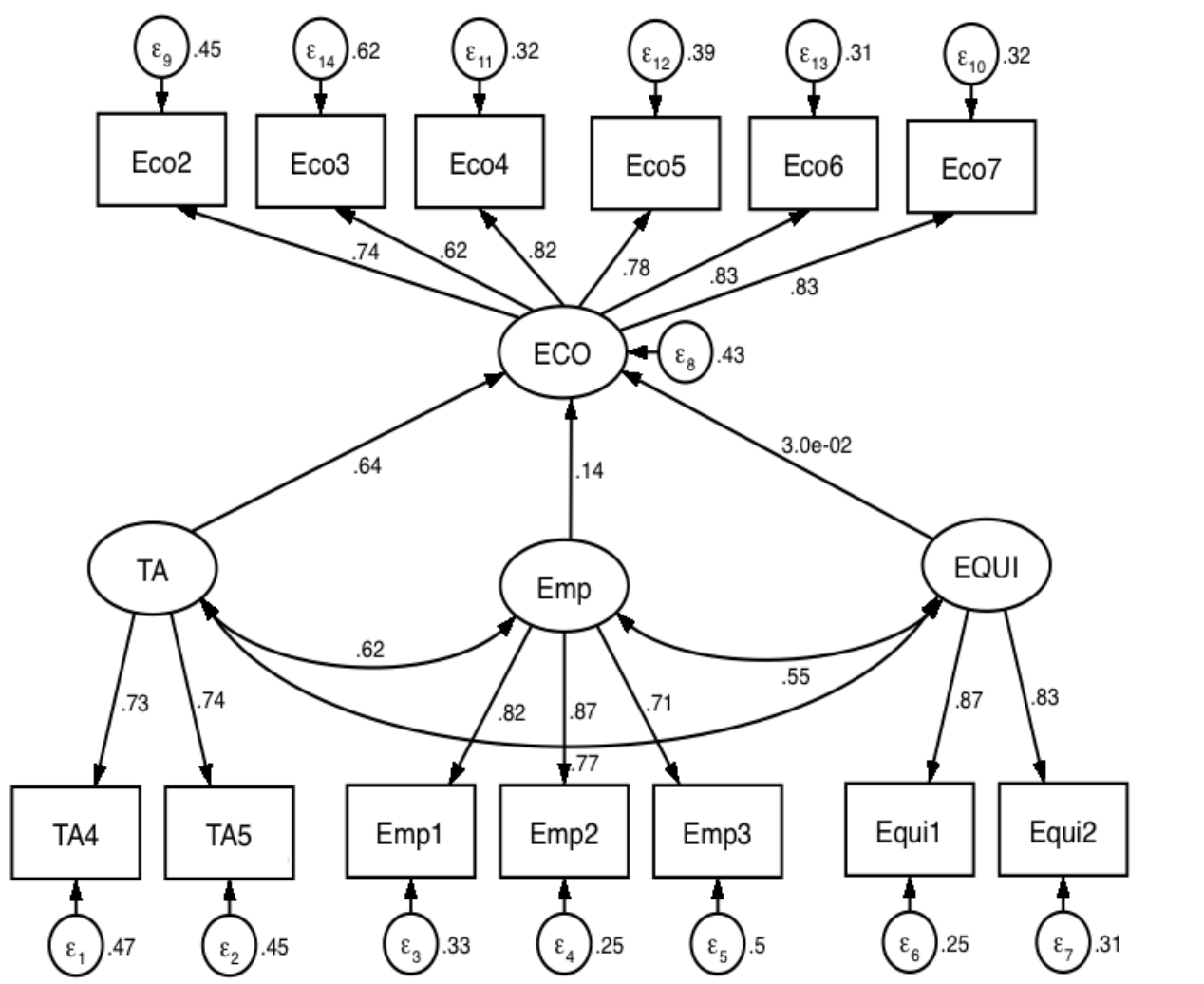

Source: Prepared by the author (2016).

The index adjustments presented by the model were acceptable, given the values found in the literature. However, some values as the $p$-value of the chi-square (0.021) provide evidence of possible differences between the actual model and the real model. Although the number of

Table 5 - Indices of the structural model

\begin{tabular}{lll}
\hline INDEX & ADJUSTMENT & RECOMMENDED VALUES \\
CMIN/DF & 1,410 & $<5,00$ (MARÔCO, 2011) \\
\hline & & $>0,05$ (HAIR et al., 2005) \\
\hline p-valor & 0,021 & $>0,90$ (HAIR et al., 2005) \\
TLI & 0,974 & $>0,90$ (HAIR et al., 2005) \\
CFI & 0,981 & $>0,05$ e <0,08 (HAIR et al., 2005) ou < 10 \\
RMSEA & 0.048 & (MARÔCO, 2011) \\
SRMR & 0.035 & $<0,08$ (HANCOCK; MUELLER, 2006) \\
CD & 0.988 & $>0,90$ (HANCOCK; MUELLER, 2006) \\
\hline
\end{tabular}

Source: Prepared by the author (2016).

observations is within the minimum of five observations per estimated parameter (Hair, Black, Babin \& Anderson, 2005) over a number interviewed people could improve these fit indices. The other indices were suitable with the literature. 
The following table shows the values of the factor loadings of each construct ecoefficiency. Only environmental training has significant charge, while the others were not acceptable values of $p$-value.There is evidence in this way that environmental

Table 6 - Load factor in eco-efficiency training promotes eco-efficiency in the company, while others, though also with positive charges do not present sufficient evidence to the same statement.

\begin{tabular}{|c|c|c|c|c|c|c|}
\hline & Coefficient & $\begin{array}{l}\text { Standard } \\
\text { deviation }\end{array}$ & $\mathrm{z}$ & $P>z$ & [Span & Trust 95\%] \\
\hline \multicolumn{7}{|c|}{ ECO <- } \\
\hline OK & 0.636 & 0.176 & 3.6 & 0,000 & 0.290 & 0.981 \\
\hline Emp & 0.141 & 0.101 & 1.4 & 0.162 & -0.057 & 0.339 \\
\hline EQUI & 0.030 & 0.154 & 0.19 & 0.848 & -0.273 & 0.332 \\
\hline
\end{tabular}

Source: Prepared by the author (2016).

Finalizing the data analysis was performed Harman test to check the possible bias caused by the single method of data collection (Podsakoff \& Organ, 1986). The test consists of a factor analysis of principal components among the items of the structural model using VARIMAX rotation. The analysis generated a result of three factors with eigenvalues greater than 1.0. These three factors accounted for $59.519 \%$ of the total variance explained of the data being the first with $44.971 \%$ of the data, the second with $8.529 \%$ of the total explained variance and the latter with $6,019 \%$ of the total variance explained.

As the result was more of a factor and all less than $50 \%$ of explanation we can say that there is evidence to corroborate the hypothesis that the model does not suffer from common bias to the method. The dimensions also generated indicated a good fit of the concepts, and only two of the twelve items are allocated out of its proper concept. Both team concepts and training were allocated together by principal component analysis.

\section{DISCUSSIONS}

The results show that for the population of respondents there was no significant difference between the number of men and women. The research hypothesis of the research, we obtained the following results: $\mathrm{H}_{1}-\quad$ T raining Environmental relates positively to the range of eco-efficiency in the business services sector.

From the analysis of the values of factor loadings of each construct eco-efficiency it is possible to say that the environmental training has significant burden, there is evidence, therefore, that environmental training promotes ecoefficiency in the company. The presented results corroborate the literature in the area, where studies show the importance and the positive influence of environmental training to achieve the environmental objectives, contributing to better environmental performance of organizations and environmental maturity (Jabbour, Jabbour, 
Teixeira \& Freitas, 2012; Jabbour, Teixeira \& Jabbour, 2013; Jabbour, 2015). Environmental training is also essential factor to overcome the challenges facing the organization for the implementation of environmental policies (Vidal-Salazar et al. 2012; Ji et al, 2012; Wagner, 2013).

Thus, the construct Environmental training, proved to be positively related to ecoefficiency in the company analyzed the service sector.

$\mathrm{H}_{2-} \quad$ And empowerment relates positively to the range of ecoefficiency in the business services sector.

The construct empowerment did not obtain acceptable value p-value. Although with positive charge also did not provide sufficient evidence for its proof. So empowerment did not show the expected positive effect .

Taking into account that according to the literature of the field, empowerment of employees improves environmental business performance (Feng, Wang \& Prajogo, 2014; Diduck, 1999) the displayed result indicates that the organization loses opportunities for improvement in the environmental area, failing to promote the empowerment of employees who are already trained in environmental issues because this empowerment for making decisions on environmental issues drives the success of enterprise management system (Massoud, Daily \& Bishop, 2011). This result brings up the discussion on the challenges to develop empowerment. The literature highlights the importance of communication (Matthews, Michelle Diaz \& Cole, 2003) and the existence of a culture that supports the empowerment of employees (Shen, Yao \& Griffith, 2006).

$\mathrm{H}_{3}$ - teamwork relates positively to the range of eco-efficiency in the business services sector.

The construct teamwork did not obtain acceptable value p-value. Although with positive charge also did not provide sufficient evidence for its proof. Thus, teamwork did not show the positive effect expected with respect to eco-efficiency.

Work on environmental teams, according to the literature, can bring environmental benefits to companies, contributing to a strategic environmental management (Jabbour, 2013) and relevant to the successful implementation of environmental sustainability programs (Longoni, Golini \& Cagliano, 2014) positively affecting the performance and environmental reputation of the organization (Dangélico, 2015), however unfinished or abandoned projects generate distrust and discourage involvement in team work (Crowley, Payne \& Kennedy, 2014).

Based on the theory of AMO, AbilityMotivation-Opportunity of Appelbaum et al. (2000), it can be concluded that the organization studied the employees are trained to environmental issues through training and development, which increases the motivation and commitment staff with environmentally appropriate actions, but is low perception of opportunity sharing knowledge and involvement of workers in problem solving environment. Thus, the teamwork should be developed and managers can empower the workers, giving them the opportunity to take greater responsibility for the task by of empowerment . 


\section{CONCLUSIONS \\ IMPLICATIONS}

AND

Designed based on a context of scarce research on GHRM and eco-efficiency in the financial service sector in Brazil, this study tested the relationship between environmental

training, empowerment and teamwork and the range of eco-efficiency in the context of a company in the Brazilian financial sector. We conducted a survey to test three hypotheses, but only one was confirmed: environmental training positively influences the eco-efficiency practices. In such a way, that company may be experiencing difficulties to put the training into practice and needs to improve teamwork and d environmental empowerment. Or employees may not be getting to work in teams and make decisions with autonomy to support the ecoefficiency. Faced with the above statements, this work contributes to companies and business leaders to emphasize the importance of investment resources for the training of managers and employees and the development of an organizational and communicational culture that encourages empowerment and teamwork increasing commitment employees to achieve the environmental objectives of the organization.

\section{Research Implications}

In view of the proposed objectives and the results achieved, it is possible to contribute to the literature, since studies carried out so far indicated the positive relationship between teamwork and empowerment for environmental performance, more precisely in industrial companies. That in the service sector company analyzed this relationship is not evident. It confirms research that demonstrates that environmental training is positively and directly related to environmental performance, which in this work was analyzed by the scope of ecoefficiency. The paper also presents an evaluation of the results of environmental training in a Brazilian company, which has not been published in the literature until now. In addition, this analysis has been carried out in the service sector, which, although very important in the Brazilian economy, In this sector.

\section{Managerial Implications}

Based on the results found, they indicate that:

1 - attention should be given to the supply and participation of managers in environmental training that encourage their commitment to environmental issues and the training of their team to promote environmentally responsible attitudes.

2- The sharing of responsibilities may promote the greater commitment of trained employees to carry out actions and strategies that improve organizational environmental performance, allowing the opening of ideas and suggestions that bring advantages to the company through bottonup strategy (which arise of the lower hierarchical levels and expand throughout the organization).

3. For the development and strengthening of teamwork in organizations, it is necessary for the culture to support this type of work, besides having reliable and confident managers, prepared to deal with the empowerment of workers and with divergent opinions that must be worked out and directed For organizational goals. 
4. Small sessions of environmental team training with general guidelines are an excellent way to include all the team in the objective of improving the environmental actions of the company, as well as to allow the knowledge of the advantages for the company in having an environmental management system in place and the Need for continuous improvement.

Given the above, this paper contributes to companies and business leaders by emphasizing the importance of investing resources for the training of managers and employees and the development of an organizational and communicational culture that favors empowerment and teamwork, increasing the commitment of The environmental objectives of the organization.

\section{LIMITATIONS AND FUTURE DIRECTIONS}

The main limitations of this study are: a single-company study, potential social respondent bias when being part of a survey in the field of sustainability.

As a research suggestion, it can be observed that the present study could be extended with the investigation of other companies in the service sector, which would allow a comparison between different realities. The use of competing models that would allow the investigation of indirect influence of the human and organizational factors studied here for environmental performance would also bring contributions to the literature, as well as the use of models in which empowerment and teamwork were mediating the relationship between environmental training and ecoefficiency, and not at the same level of TA. A longitudinal survey in the same company could also be carried out, provided that programs of empowerment and teamwork were developed, allowing the analysis that, if there was a greater development of the two factors, this would imply in an increase of ecoefficiency in the company, allowing to verify if From a certain level or from which level the empowermet and teamwork directly influence the environmental performance in companies of the service sector.

\section{REFERENCES}

Appelbaum, E., Bailey, T., Berg, P. \& Kalleberg, A. (2000) Manufacturing Advantage: Why High-Performance Work Systems Pay off. NY: ILR Press..

ASSOCIAÇÃO BRASILEIRA DE NORMAS TÉCNICAS - NBR ISO 14001:2004 - Sistemas de gestão ambiental - requisitos com orientações para uso. Rio de Janeiro: ABNT.

Costa, F. J. (2011) Mensuração $e$ desenvolvimento de escalas: Aplicações em Administração. Rio de Janeiro: Editora Ciência Moderna Ltda.

Crowley, M., Payne, J. \& Kennedy, E. (2014) Working better together Empowerment, panopticon and conflict approaches to teamwork. Economic and Industrial Democracy, 35(3), 483 -506.

Daily, B.F., Bishop, J.W. \& Massoud, J.A. (2012) The role of training and empowerment in environmental performance: A study of the Mexican maquiladora industry . International Journal of Operations and Production Management, 32(5), 631-647.

Daily, B.F., Huang, S. C. (2001). Achieving sustainability through attention to human resource factors in environmental 
management. International Journal of Operations and Production Management, 21(12), 1539-1552.

Dangélico, R. M.. (2015) Improving Firm Environmental Performance and Reputation: The Role of Employee Green Teams. Business Strategy and the Environment, 24(8), 735-749.

Del Brio, J.A., Junquera, B., Ordiz, M. (2008). Human resources in advanced environmental approaches-a case analysis. International Journal of Production Research, 46 (21), 6029-6053.

Diduck, A. (1999) Critical education in resource and environmental management: Learning and empowerment for a sustainable future. Journal of Environmental Management, 57, 85-97.

Feng, T., Wang, D. \& Prajogo, D. (2014) Incorporating human resource management initiatives into customer services: Empirical evidence from Chinese manufacturing firms. Industrial Marketing Management, 43(1), 126-135.

Gotschol, A., De Giovanni, P., Vinzi, V. E. (2014). Is environmental management an economically sustainable business? Journal of Environmental Management, 144, 73-82.

Hair, J. F. Jr., Black, W. C., Babin, B. J., \& Anderson, R. E. (2005) Análise multivariada de dados. 5. ed. Porto Alegre: Bookman.

Hair, J.F. Jr., Ringle, C.M. \& Sarstedt, M. (2011) PLS-SEM: indeed a silver bullet. $J$. Market. Theor. Pract. 19(2), 139 -151.

Hale, M. (1995) Training for environmental technologies and environmental management. Journal of Cleaner Production, 3(1-2), 19-23.

Hancock, G.R. \& Mueller, R. O. (2006) Structural equation modeling: A second course. Greenwich, CT: Information Age Publishing, Inc. 448 p.

Heras-Saizarbitoria, I., Arana, G.; Boiral, O. (2016). Outcomes of Environmental Management Systems: the Role of Motivations and Firms' Characteristics. Business Strategy and the Environment, 25 (8), 545-559.

Hodson, R. (2010) Work group effort and rewards: The roles of organizational and social power as contexto. Organization Studies, 31 (7), 895-916.

Hridlicka, H. A. (2009) As boas práticas de gestão ambiental e a influência no desempenho exportador: um estudo sobre as grandes empresas exportadoras brasileiras. 2009. Tese - Faculdade de Economia, Administração e Contabilidade, Universidade de São Paulo, São Paulo, Brasil.

Huppes, G., Ishikawa, M. (2005). A framework for quantifies eco-efficiency analysis. Journal of Industrial Ecology, 9 (4), 25-41.

Ismail, I. R., Hamid, R. A. \& Idris, F. (2012) PLS application in Journals of Operations Management: a review. In GLOBAL CONFERENCE ON OPERATIONS AND SUPPLY CHAIN MANAGEMENT, 1-6.

Jabbour, C. J. C. (2013) Environmental training in organisations: From a literature review to framework for future research. Resources, Conservation and Recycling, 74, 144-155.

Jabbour, C.J.C. (2015) Environmental training and environmental management maturity of Brazilian companies with ISO14001: empirical evidence. Journal of Cleaner Production, 96(3746), 331-338.

Jabbour, C.J.C., Jabbour, A.B.L., Teixeira, A.A. \& Freitas, W.R.S. (2012) 
Environmental development in Brazilian companies: The role of human resource management. Environmental Development, 3(1), 137-147.

Jabbour, C.J.C., Santos, F. C. A., Fonseca, S. A. \& Nagano, M. S. (2013) Green teams: understanding their roles in the environmental management of companies located in Brazil. Journal of Cleaner Production, 46, 58-66.

Jabbour, C.J.C., Santos, F. C. A., Nagano, M. S. (2010). Contributions of HRM throughout the stages of environmental management: methodological triangulation applied to companies in Brazil. International Journal of Human Resource Management, 21(7), 1049-1089.

Jabbour, C.J.C., Teixeira, A.A. \& Jabbour, A.B.L.S. (2013) Treinamento ambiental em organizações com certificação ISO 14001: Estudo de múltiplos casos e identificação de coevolução com a gestão ambiental. Produção, 23(1), 80-94.

Ji, L., Huang, J.; Liu, Z., Zhu, H. \& Cai, Z. (2012) The effects of employee training on the relationship between environmental attitude and firms' performance in sustainable development. International Journal of Human Resource Management, 23(14), 2995-3008.

Joardar, A., Sarkis, J. (2014). A General analysis of sustainability, institutions and emerging economies. Latin American Journal of management for sustainable development, 1 (4).

Kitazawa, S.; Sarkis, J. (2000). The relationship between ISO 14001 and continuous source reduction programs. International Journal of Operations and Production Management, v. 20, n. 2, 225248.

Krajnc, D., Glavic, P. (2005). A model for integrated assessment of sustainable development. Resources, Conservation and Recycling, 43(2), 189-208.

Longoni, A., Golini, R. \& Cagliano, R. (2014) The role of New Forms of Work Organization in developing sustainability strategies in operations. International Journal of Production Economics, 147, 147-160.

Madsen, H., Ulhoi, J.P. (2001). Greening of human resources: Environmental awareness and training interests within the workforce. Industrial Management and Data Systems, 101(2), 57-63.

Marôco, J. (2010). Análise de equações estruturais: Fundamentos teóricos, software \& aplicações. ReportNumber, Ltda.

Marshall, D., Mccarthy, L., Heavey, C. \& MacGrath, P. (2015) Environmental and social supply chain management sustainability practices: construct development and measurement. Production Planning \& Control, 26(8), 673-690.

Martín-Peña, M. L., Díaz-Garrido, E., Sánches-Lópes, J.M. (2014). Analysis of benefits and difficulties associated with firms' environmental management systems: the case of Spanish automotive industry. Journal Cleaner Production, 70 (1), 220230.

Massoud, J. A., Daily, M. B., \& Bishop, J. W. (2011) Perceptions of environmental management systems. Industrial Management \& Data Systems, 111(1), 5 19.

Massoud, J. A., Daily, M. B., Bishop, J. W. (2011). Perceptions of environmental management systems. Industrial Management \& Data Systems, 111(1), 5-19.

Matthews, R.A., Michelle Diaz, W. \& Cole S.G. (2003) The organizational 
empowerment scale. Personnel Review, 32(3), 297-318.

Munck, L., Borim-De-Souza, R. B. (2009). Gestão por competências e sustentabilidade empresarial: em busca de um quadro de análise. Gestão e Sociedade, 3(6), 254-287.

Paille, P., Chen, Y., Boiral, O. \& Jin, J. (2014) The Impact of Human Resource Management on Environmental Performance: An Employee-Level Study. Journal Business Ethics, 121(3), 451-466.

Perron, G.M., Côté, R.P. \& Duffy, J.F. (2006) Improving environmental awareness training in business. Journal of Cleaner Production, 14(6-7), 551-562.

Piaralal, N. K., Mat. N., Piaralal, S. K., Bhatti, M. A. (2004). Human resource management factors and service recovery performance in Malaysian life insurance industry, European Journal of Training and Development, 38(6), 524 - 552.

Podsakoff, P. M. \& Organ, D. W. (1986) Self-reports in organizational research: Problems and prospects. Journal of management, 12(4), 531-544.

Prajolo, D., Tang, A.K.Y., Lai, K. H. (2014). The diffusion of environmental management system and its effect on environmental management practices. International Journal of Operations \& Production Management, 34 (5), 565 -585.

Renwick, D.W., Redman, T., Maguire, S. Green Human Resource Management: A Review and Research Agenda. (2013). International Journal of Management Reviews, 15(1), 1-14.

Salgado, V. G. (2004) Proposta de indicadores de ecoeficiência para o transporte de gás natural. Dissertação (Mestrado em Ciências do Planejamento
Energético)-Universidade Federal do Rio de Janeiro.

Sammalisto, K., Brorson, T. (2008). Training and communication in the implementation of environmental management systems (ISO 14001): a case study at the University of Gävle, Sweden. Journal of Cleaner Production, 16 (3), 299309.

Savitz, A. W. \& Weber, K. (2007) A empresa sustentável: o verdadeiro sucesso é lucro com responsabilidade social $e$ ambiental. Rio de Janeiro: Elsevier.

Sênior, B., Swailes, S. (2007). Inside Management Teams: Developing a Teamwork Survey Instrument. British Journal of Management, 18(2), 138-153.

Shen, L., Yao, H. \& Griffith, A. (2006) Improving environmental performance by means of empowerment of contractors. Management of Environmental Quality, 17(3), 242-257.

Sisinno, C.L.S., \& Moreira, J. C. (2005) Ecoeficiência: um instrumento para a redução da geração de resíduos e desperdícios em estabelecimentos de saúde. Cadernos de Saúde Pública, 21(6), 18931900.

Slatten, T. (2010), “Do employees' feelings really matter in service-quality management?", European Business Review, 22(3), 318-338.

Strachan, P.A. (1996) Achieving environmental excellence through effective teamwork. Team Performance Management: an International Journal, 2 (1), 25-29.

Tariq, S., Jan, F.A. \& Ahmad, M. S. (2016) Green employee empowerment: a systematic literature review on state-of-art 
in green human resource management. Quality and Quantity, 50(1), 237-269.

Tung, A., Baird, K. \& Schoch, H. (2014) The relationship between organisational of environmental management. Journal of Environmental Management, 144(1), 186196.

Unnikrishnan, S., Hegde, D.S. (2007). Environmental training and cleaner production in Indian industry-A micro-level study. Resources, Conservation and Recycling, 50 (4), 427-441.

Vachon, S. \& Klassen, R.D. (2008) Environmental management and manufacturing performance: The role of collaboration in the supply chain. International Journal of Production Economics, 111(2), 299-315.

Vidal-Salazar, M. D., Cordón-Pozo, E. \& Ferrón-Vilchez, V. (2012) Human resource management and developing proactive environmental strategies: The influence of environmental training and organizational learning. Human Resource Management, 51(6), 905-934.

Wagner, M. (2013) 'Green' Human Resource Benefits: Do they Matter as Determinants of Environmental Management System Implementation? Journal of Business Ethics, 114(3), 443456.

Wagner, M. A. (2015). European perspective on country moderation effects: Environmental management systems and sustainability-related human resource benefits. Journal of World Business, 50 (2), 379-388.

World Business Council for Sustainable Development (WBCSD). Eco-efficiency learning module. Disponível em $<$ http://www.wbcsd.org/pages/EDocument/
EDocumentDetails.aspx?ID=13593>. Acesso em 14 maio 2014.

Yavas, U., Karatepe, O.M., Avci, T. \& Tekinkus, M. (2013) "Antecedents and outcomes of service recovery performance: an empirical study of front-line employees in Turkish banks". International Journal of Bank Marketing, 21(5), 255-265.

Yavas, U., Karatepe, O.M., Avci, T., Tekinkus, M. (2013). "Antecedents and outcomes of service recovery performance: an empirical study of front-line employees in Turkish banks", international journal of bank marketing, 21(5), 255-265.

Zibarras, L. D. \& Coan, P. (2015) HRM practices used to promote proenvironmental behavior: a UK survey. The International Journal of Human Resource Management, 26(16), 2121-2142. 